\title{
Editorial \\ Special Issue on Discovery and Research on Aquatic Microorganisms
}

\author{
Anna Poli *(D) and Valeria Prigione *(D) \\ Mycotheca Universitatis Taurinensis, Department of Life Sciences and Systems Biology, University of Torino, \\ Viale Mattioli 25, 10125 Torino, Italy \\ * Correspondence: anna.poli@unito.it (A.P.); valeria.prigione@unito.it (V.P.)
}

Citation: Poli, A.; Prigione, V. Special Issue on Discovery and Research on Aquatic Microorganisms. Appl. Sci. 2021, 11, 11973. https://doi.org/ 10.3390/app112411973

Received: 13 December 2021

Accepted: 14 December 2021

Published: 16 December 2021

Publisher's Note: MDPI stays neutral with regard to jurisdictional claims in published maps and institutional affiliations.

Copyright: (c) 2021 by the authors. Licensee MDPI, Basel, Switzerland. This article is an open access article distributed under the terms and conditions of the Creative Commons Attribution (CC BY) license (https:// creativecommons.org/licenses/by/ $4.0 /)$.

\section{Introduction}

The Special Issue entitled "Discovery and Research on Aquatic Microorganisms" wished to improve our knowledge on microorganisms living in aquatic environments.

Aquatic environments, including freshwater and marine ecosystems, raw and treated sewage, and sludge and sediments host a huge variety of microorganisms that mediate the recycling of dissolved organic carbon and recalcitrant substrata into the food webs and the atmosphere. Archaea, bacteria, microalgae, filamentous fungi and yeasts play a key role in degradation processes and many of them are used or have the potential to be harnessed in bioremediation. The importance of aquatic microorganisms has to be found in their physiology and behavior: they can sink or float, some are motile, others adhere to a range of biotic and abiotic substrates (e.g., algae, invertebrates, sediments, driftwood, etc.), they can form biofilms on surfaces, remain planktonic, or produce a broad diversity of bioactive compounds.

This Special Issue includes four research articles and one review paper dealing with the applicative potential and the biodiversity of aquatic microorganisms.

Amin et al. [1] faced the problem of bacterial disease outbreakes in aquaculture. By knowing that biofilms formation together with antibiotic resistance protects marine pathogens like Vibrio campbelli and Vibrio parahemolyticus against antimicrobials, they successfully applied and evaluated the antimicrobial properties and the biofilm inhibition activity of silver ion-236 exchanged zeolite (AgZ).

The importance of filamentous fungi was assessed by Poli et al. [2], Romero-Hernández et al. [3], and by Dobretsov et al. [4]. In the first case, the authors, by applying morphological, molecular and phylogenetic analyses, described the novel Corollospora mediterranea species complex (CMSC), isolated from different substrates in the Mediterranean Sea. Species affiliated to the genus Corollospora are known to produce bioactive compounds and can be possibly exploited as bioremediators of oil spill contaminated beaches, thus indicating a biotechnological potential of the newly introduced species [2].

Following the Deepwater Horizon oil spill, interest in characterizing the fungal diversity in the Gulf of Mexico (GoM) rapidly increased. Romero-Hernández et al. [3] focused on heavy crude oil (HCO) and extra-heavy crude oil, evaluating the ability of fungal strains isolated from deep-sea sediments of the GoM to degrade them. They demonstrated that species of Alternaria, Penicillium and Stemphylium, can use HCO as its sole carbon source, while a strain of Alternaria was the only one to grow in the presence of EHCO, displaying excellent degradative properties.

Dobretsov and collaborators [4], painted plastic panels with a copper-based antifouling paint and exposed them to biofouling for months. The authors then identified six fungal isolates (Alternaria sp., Aspergillus niger, A. terreus, A. tubingensis, Cladosporium halotolerans, and $C$. omanense) from biofilms developed on the surface of the antifouling paint, demonstrating their resistance to copper. Although further investigations are required, these findings can have implications in the biofouling industry. 
Finally, Bolivar-Galiano et al. [5], contributed with a review article focused on the phototroph biodiversity reported in monumental fountains. Since many phototrophic organisms that develop on stone material are responsible for biodeterioration, the authors wished to draw up a guide for interested professionals in the field of conservation, providing simplified dichotomous keys for cyanobacteria, green algae, and diatoms.

The articles published in this Special Issue confirm the importance (both positive and negative), the role, and the possible biotechnological exploitation of different organisms in aquatic ecosystems.

Funding: This research received no external funding.

Conflicts of Interest: The authors declare no conflict of interest.

\section{References}

1. Amin, Z.; Waly, N.A.; Arshad, S.E. Biofilm Inhibition and Antimicrobial Properties of Silver-Ion-Exchanged Zeolite A against Vibrio spp Marine Pathogens. Appl. Sci. 2021, 11, 5496. [CrossRef]

2. Poli, A.; Bovio, E.; Perugini, I.; Varese, G.C.; Prigione, V. Corollospora mediterranea: A Novel Species Complex in the Mediterranean Sea. Appl. Sci. 2021, 11, 5452. [CrossRef]

3. Romero-Hernandez, L.; Velez, P.; Betanzo-Gutierrez, I.; Camacho-Lopez, M.D.; Vazquez-Duhalt, R.; Riquelme, M. Extra-Heavy Crude Oil Degradation by Alternaria sp. Isolated from Deep-Sea Sediments of the Gulf of Mexico. Appl. Sci. 2021, 11, 6090. [CrossRef]

4. Dobretsov, S.; Al-Shibli, H.; Maharachchikumbura, S.S.N.; Al-Sadi, A.M. The Presence of Marine Filamentous Fungi on a Copper-Based Antifouling Paint. Appl. Sci. 2021, 11, 8277. [CrossRef]

5. Bolivar-Galiano, F.; Cuzman, O.A.; Abad-Ruiz, C.; Sanchez-Castillo, P. Facing Phototrophic Microorganisms That Colonize Artistic Fountains and Other Wet Stone Surfaces: Identification Keys. Appl. Sci. 2021, 11, 8787. [CrossRef] 